\title{
A gamifikáció szerepe a zeneoktatásban
}

\author{
Kiss Bernadett ${ }^{1}$ és Asztalos Andrea ${ }^{2}$ \\ ${ }^{1}$ Szegedi Tudományegyetem \\ ${ }^{2}$ Szegedi Tudományegyetem Ének-Zene Tanszék
}

\begin{abstract}
Absztrakt
A tanulmány a gamifikáció módszerét, valamint annak oktatásban, ének-zene oktatásban történő alkalmazási lehetőségeit mutatja be. A gamifikáció egy olyan, egyre nagyobb népszerűségnek örvendő módszer, mely az oktatásban is használható. A módszer legfőbb jellemzője, hogy az élet olyan területein használ játékos elemeket (például pontozás és szintek), ahol a környezet alapvetően nem játékos. Ilyen, nem játékos környezetnek tekinthetők az oktatás, illetve a tanulás különböző területei is. A módszer során a tanulók játékos szerepbe bújva szereznek pontokat a tanórai feladatokért. A játékos elemek lehetővé teszik, hogy a diákok úgy tanuljanak, hogy közben szórakoznak. A módszer egyik előnye, hogy képes motiválni a tanulókat. A tanulmányban példák olvashatók arra, hogyan lehet alkalmazni a gamifikáció módszerét a tanítás során, valamint az ének-zene órákon.
\end{abstract}

Kulcsszavak: gamifikáció, játékosítás, ének-zene oktatás, zeneoktatás, énekórai motiváció

\section{Bevezetés}

A zene jelen van az emberek mindennapjaiban, hiszen zenét hallgatunk, ha jó kedvünk van, ha rossz kedvünk van, ha tanulunk, ha takarítunk, ha vezetünk. Zene szól a boltokban és a bevásárlóközpontokban is. Ezek alapján azt gondolnánk, amennyiben valami ennyire fontos részét képezi az ember életének, akkor szívesen tanulja azt, illetve meg szeretné érteni. Ehhez képest több, az ének-zene tantárggyal kapcsolatos kutatás arról számol be, a diákok nem kedvelik az énekórákat (Chrappán, 2017; Csíkos, 2012; Janurik \& Józsa, 2018; Janurik et al., 2020, 2021; Pintér \& Csíkos, 2020; Pintér, 2018, 2020).

Az ének-zene tantárgy élményszerü oktatására számos lehetőség van, melyek közül egy lehet a gamifikáció módszerének bevezetése. A gamifikáció egy olyan, az oktatásban is egyre inkább elterjedő módszer, mely játékos elemeket használ fel egy cél elérése érdekében. Tehát játékos elemeket emel be egy nem játékos környezetbe (Kusuma et al., 2018). Célja, hogy a tanuló - a „játékos” - úgy sajátítson el új tudást, hogy nem veszi észre a tanulás fo- 
lyamatát. A gamifikációs módszer kialakításához egy olyan szabályrendszert kell létrehozni, amely motiválja a játékost a feladat elvégzésére. Ehhez az órai feladatokat át kell csoportosítani és játékos elemekkel kell vegyíteni (Koivisto \& Hamari, 2019). Játékos elemek közé tartozhat a feladatok részfeladatokra bontása, célok meghatározása, a játék háttértörténetének megadása, folyamatos visszacsatolás a játékos fejlődéséről vagy a fejlődési szintek megnevezése. Ahhoz, hogy a tanuló azt érezze, egy játékban vesz részt, a rendszernek olyan kritériumoknak kell megfelelnie, melyek a szórakozás alapvető elemei: elégedettségérzet, kihívás, felfedezés, közösség, önkifejezés, fantázia, elismerés, narráció (Kusuma et al., 2018).

A tanulmány célja, hogy összefoglalja a gamifikáció módszerének történetét, illetve előzményeit, valamint betekintést nyújtson a módszer felépítésébe és mủködési elvébe. Ezen kívül külföldi és hazai példát nyújt a gamifikáció zeneoktatásban történő alkalmazására .

\section{Történeti áttekintés}

A gamifikáció mostanában egyre divatosabb kifejezés. Az 1. ábrán látható diagram a Google Trends szolgáltatással készült, ami a Google-kereséseket figyeli. A szolgáltatás 2004 óta vizsgálta a világháló kereséseit. Az ábráról leolvasható, hogy a "gamifikáció” szó keresési előzményeiben 2010-től figyelhető meg a növekedés.

\section{1. ábra}

A „gamifikáció" szó Google keresési statisztikája ${ }^{1}$

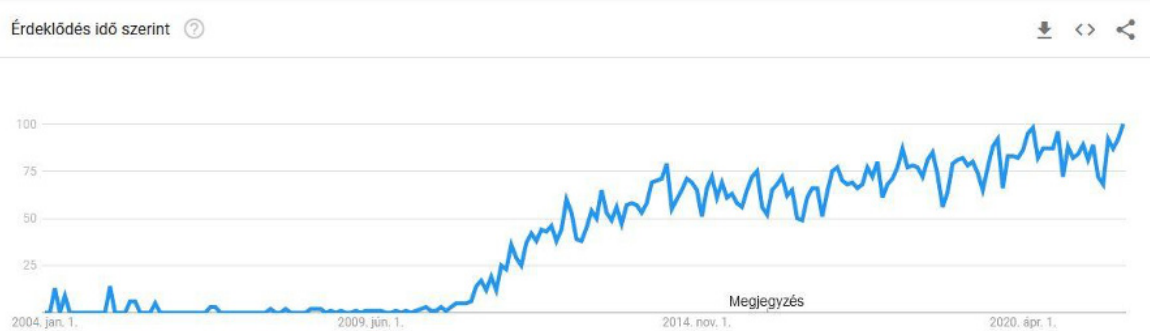

Habár a gamifikáció - mint módszer - föként a 21. század terméke, már sokkal korábban is megjelent bizonyos formákban, a története egészen a 19. század végéig nyúlik vissza.

Az 1896-ban alapult Sperry and Hutchinson vállalat zöld bélyegeket árult szupermarketeknek, illetve más üzleteknek. Azok a vásárlók, akik ezekben a boltokban vásároltak, egy bizonyos összeg elköltése után kaptak egy bélyeget, amelyet egy albumban gyüjthettek. Ha összegyűlt a megadott bélyeg-

${ }^{1}$ Forrás: https://trends.google.com/trends/explore?date=all\&q=\%2Fm\%2F0cm $8 x v 9$ 
szám, elpostázták a vállalatnak, és a bélyegekért cserébe egy katalógusból választott termékben részesülhettek (Christians, 2018).

1973-ban könyv (Game of Work) született arról, hogyan lehetne munkahelyi környezetben játékos elemeket alkalmazni. A szerző - Charles Coonradt - azt vizsgálja, hogyan lehet az, hogy embereknek azért fizetnek a munkahelyükön, hogy együtt dolgozzanak és mégis nehézkesen érik el a célokat, nem tudnak csapatban dolgozni. Ezzel szemben egy kosárlabdameccsen olyan könnyedén tudnak együtt dolgozni a játékosok annak érdekében, hogy megnyerjék a meccset. Coonradt arra a következtetésre jutott, hogy a kettő közti fö különbség a visszacsatolásban van. A sportjátékokban, illetve más játékokban, a visszacsatolás azonnal megtörténik a játék során, hiszen láthatók a gólok, a megszerzett pontok. Ezzel szemben a munkahelyi környezetben nem ilyen gyakori a visszajelzés a dolgozók munkájáról. Ezek alapján a szerző úgy gondolta, eredményes lehet, ha a folyamatos visszacsatolást beépíti a munka világába. A munka és a játék lehetséges kapcsolatáról szóló könyv egyike az első gamifikációval kapcsolatos tanulmányoknak (Coonradt, 1973 idézi Christians, 2018).

1978-ban jelent meg az úgy nevezett MUD (Multi-User Dungeon) első próbaverziója. Ez tekinthető az első többfelhasználós börtönjátéknak, valamint az első virtuális világban megjelenő játéknak. Olyan elemeket tartalmazott, mint például a szerepjáték, felhasználó-felhasználó elleni küzdelem, valamint online chat, online kommunikáció. A szövegalapú játékban a játékosok elolvashatták a szobák, tárgyak, más játékosok, illetve tevékenységek leírását és írásban tudtak kommunikálni a többi játékossal, illetve írásban adtak utasításokat a rendszernek. Az egyéneket egy-egy karakter reprezentálja, az események valós időben történnek, egy-egy lépést követően azonnali reakció várható (Bartle, 2004).

A szövegalapú online játék fontos mérföldkő az online szocializáció és kooperáció kialakulásának történetében, ugyanakkor nagyban hozzájárult a gamifikáció fejlődéséhez is (Christians, 2018). Rámutatott arra, hogy az egyének milyen jól együtt tudnak müködni egy játékos környezetben.

A gamifikációval kapcsolatos első tudományos írások az 1980-as években jelentek meg. Thomas W. Malone felismerte a játékos elemek alkalmazásának lehetséges pozitív hatásait, ezért kipróbálta más területeken is, többek között az oktatásban (Christians, 2018). Malone a következő kérdésekre kereste a választ:

- Mitől lesznek a dolgok szórakoztatóak?

- Hogyan lehet olyan utasításokat adni a tanulóknak, amelyek felkeltik az érdeklődésüket és a tanulás folyamatához is hozzáárulnak?

- Miért olyan magával ragadóak a számítógépes játékok?

- Hogyan lehetne ezeket az elemeket az oktatásban úgy felhasználni, hogy az érdekesebb és élvezetesebb legyen?

Malone arra a következtetésre jutott, hogy a motiváltságot nagyban elösegíti, ha a tanulóknak van választási lehetőségük, kiválaszthatják, milyen feladattal 
szeretnének foglalkozni. Mindezek mellett Malone szerint a versengés és a kooperáció is hozzájárult a belső motiváltsághoz (Malone, 1981).

A gamifikáció (más szóval: játékosítás) a "gamification” angol szóból származik, melynek a szótöve a "game”, játék. A gamifikációt mint kifejezést Nick Pelling játéktervező alkotta 2002-ben. Pelling egy 2012-es blogbejegyzésben ír, az általa alkotott fogalom keletkezéséről. Miközben azon gondolkozott, hogyan tudná használni a játékos elemeket (amelyeket játéktervezőként már alkalmazott) a kereskedelmi elektronikus eszközöknél (például mobiltelefonoknál), egy szándékosan csúnya szó, a gamifikáció jutott eszébe. A kifejezés alatt a játékos elemek elektronikus tranzakcióban való használatát értette (Pelling, 2012).

\section{A gamifikáció}

\section{A gamifikáció fogalma}

A Pelling által 2002-ben alkotott fogalom mára már sokkal tágabb jelentéssel bír. Számtalan definíció található könyvekben, különböző internetes fórumokon, illetve szótárakban egyaránt. A Cambridge szótár szerint a gamifikáció - „the practice of making activities more like games in order to make them more interesting or enjoyable" - az a folyamat, amely a tevékenységeket játékszerübbé teszi annak érdekében, hogy azok érdekesebbek és élvezetesebbek legyenek.

Andrzej Marczewski webfejlesztő, 2014-ben írt cikkében harminc, a gamifikációval kapcsolatos, definíciót gyűjtött össze és rendszerezte. A definíciók leírószavait sorba állította aszerint, hogy milyen gyakran fordultak elő. A leggyakoribb szavak láthatóak a 2. ábrán.

\section{2. ábra}

A definíciók leggyakoribb kifejezései (Marczewski, 2014)

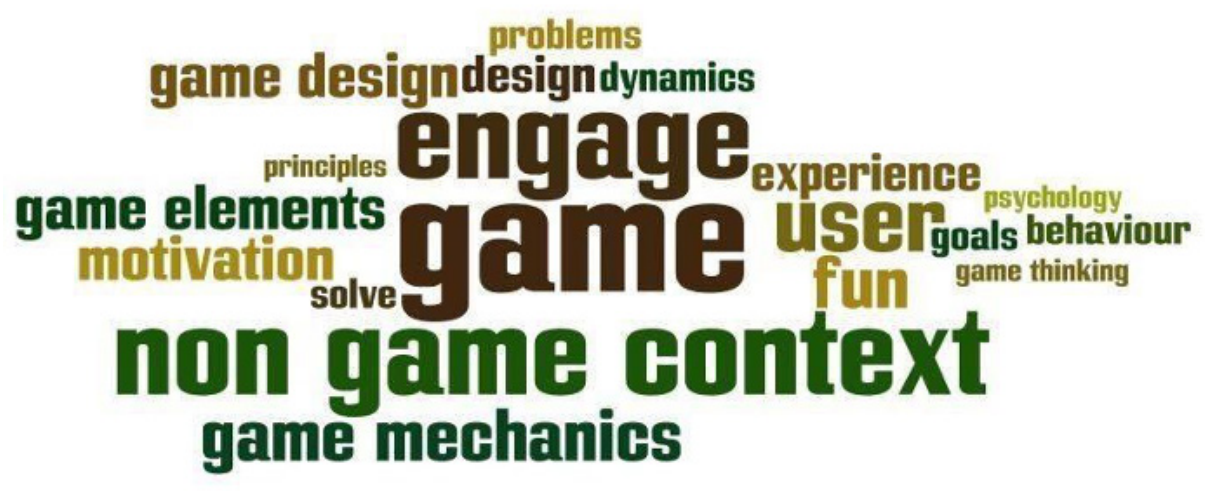


Ezek alapján a három leggyakrabban használt kifejezés a „játék”, az „elköteleződés” és a "nem játékos környezet”. Ezeken kívül még meghatározó szerepet játszanak többek között a "szórakozás”, a "motiváció" és a „játékos elemek" kifejezések. Marczewski ezek alapján megfogalmazta a gamifikáció legegyszerűbb leírását, miszerint a gamifikáció több játékszerü élmény megteremtése nem játékos környezetben. Tehát a módszer olyan ötleteket alkalmaz annak érdekében, hogy még élvezetesebb legyen az adott tevékenység, amelyeket a játékokban a kezdetektől fogva megtalálhatunk (Marczewski, 2014).

A Marczewski által vizsgált definíciók közé tartozik például Erika Webb meghatározása, miszerint a gamifikáció a játékdinamikák alkalmazása az elköteleződés érdekében, illetve a weboldalak és applikációk használata. Kevin Werbach szerint a játékosítás a játékelemek és játéktervezési technikák alkalmazása nem játékos környezetben. A gamifikációs körök egyik fő alakja, Sebastian Deterding is egyszerüen fogalmaz. Deterding meghatározása szerint a gamifikáció a játékszerű elemek alkalmazása a nem játékos környezetben (Marczewski, 2014).

Az előbb említett definíciókat és a 2. ábrán is kiemelt leírószavakat figyelembe véve Fromann Richárd (2017) új definíciót fogalmazott meg, melyben megpróbálta összegezni a fóbb elemeket: „A gamification a játékélményhez szükséges játékelemek, játékmechanizmusok és játékdinamikák alkalmazását jelenti az élet - játékon kívüli - területein azzal a céllal, hogy az adott folyamatokat érdekesebbé és hatékonyabbá tegye." (Fromann, 2017, p. 111).

\section{Hogyan müködik a gamifikáció?}

A következőkben a tanulmány arra tér ki, milyen elemi lehetnek a gamifikációnak, elsősorban az oktatás területén. A felépítését leginkább úgy lehet elképzelni, mint a videójátékok jutalmazási rendszerét. A játékosok, illetve ebben az esetben a tanulók, választanak maguknak egy karaktert, amely játék közben az önkifejezésük jelentős motívumaként jelenik meg. Ez nem csak a karakterük kinézetében nyilvánul meg, hanem az általuk összegyűjtött javak, készségek, képességek jellegében is (Fromann, 2017).

A gamifikáció elengedhetetlen kelléke a pontrendszer. A pontokat bizonyos feladatok után kapják a tanulók. Előre meg kell határozni, hogy miért mennyi pontot lehet kapni, így a tanulók is tisztában lehetnek a lehetőségeikkel. Egy jól kialakított pontrendszerrel a tanulókat arra lehet motiválni, hogy minél több pontot akarjanak elérni (Fromann, 2017).

Bizonyos pontszámok után szintet lehet lépni, ahol nehezebb feladatok következnek. A motiváció fenntartásához fontos, hogy a kezdeti alapszintet úgy kell beállítani, hogy nagyon könnyen teljesíthető legyen. A további szintek nehézségének nem feltétlen kell egyenletesen növekednie, de arra ügyelni kell, hogy ne legyen egy szint az előzőhez képest teljesíthetetlen, hiszen akkor a kudarcélmény hatására elveszhet a motiváció (Fromann, 2017). 
Mind a feladatok után kapott pontok, mind a szintek folyamatos visszajelzést adnak a tanuló jelenlegi tudásáról és fejlődéséről. A már korábban említett Charles Coonradt által írt Game of Work című mü is foglalkozik a visszacsatolással, hiszen ez egy fontos motivációs elem. Minden tanuló 0 pontról indul, így a visszacsatolás szinte kizárólag pozitív, hiszen egyre több és több pontja lesz mindenkinek (Coonradt, 1973 idézi Christians, 2018).

A folyamatos visszacsatoláshoz szintén hozzájárul, hogy a tanulók a pontjaikat egy rangsoron is láthatják. A rangsor alapvetően egy eredményjelző tábla, melyen valamennyi tanuló elért eredménye szerepel. Fromann (2017) Játékoslét címü könyvében arról ír, „fontos, hogy a játékos mindig lássa, milyen helyet foglal el az adott környezetben másokhoz képest". Tehát a tanulónak látnia kell, hogy a rangsorban kik helyezkednek el előtte, illetve utána. Habár a rangsornak köszönhetően versenyhelyzet alakulhat ki az osztályban, jól irányított körülmények között építő lehet. A játékok során is versenyeznek egymással a felhasználók, ez adja a motivációt, ez lendíti előre a cselekményt. Tehát a tanulási folyamat során is a versengés a teljesítményük fokozására bíztahattja a tanulókat.

A következő fontos elem a cél. Minden feladatnak megvan a maga célja, valamint a fő cél, hogy a tanuló élvezze a tanulás folyamatát és legyen eléggé motivált ahhoz, hogy minél magasabb szintet akarjon elérni. Ennél a pontnál fontos megemlíteni azt, hogy míg a játéknak az a célja, hogy szórakoztasson, addig a játékosításnak - gamifikációnak - minden eseteben valamilyen játékon kívüli haszna van. Tehát a szórakozás itt nem cél, hanem egy olyan eszköz, amely motiválja a diákokat a tanulásra (Fromann, 2017).

Az utolsó pont a szabályzat. Mint minden videójátéknak vagy társasjátéknak, a gamifikációnak is meg kell határozni a szabályrendszerét. Ebben bizonyos mértékig a diákok is részt vehetnek. A megszokott sémákat, miszerint a tanulókat 1-től 5-ig tartó skálán értékeli az oktató, bizonyos mértékig át kell formálni. Ellenben, a tantervi követelmények miatt nem szabad elhagyni sem. A szabályzat kialakításakor meg kell határozni, milyen feladat mennyi pontot ér, a szintlépéshez szükséges ponthatárokat és nem utolsó sorban azt, hogy mindezért a tanulók milyen jutalmat, milyen osztályzatot fognak kapni.

\section{Miért hasznos a gamifikáció?}

A gamifikációs módszer segítségével olyan képességeket sajátíthatnak el a tanulók, melyek a 21. század kihívásaiban elengedhetetlenek. Ezek a képességek hozzájárulnak ahhoz, hogy a tanuló a jövőben jól tudjon alkalmazkodni a környezetéhez, megtalálja a számára szükséges információt, együtt tudjon dolgozni másokkal és saját magára és az idejére is oda tudjon figyelni. Olyan képességek ezek, amiket nem lehet egyik pillanatról a másikra elsajátítani, fontos hozzá az idő és a türelem. Prievara Tibor (2015), A 21. századi tanár című könyvében öt ilyen képességről ír: együttműködés, tudásépítés, IKThasználat, valós problémák megoldása, valamint innováció és önszabályozás. 
Véleményünk szerint, az együttmüködés a csapatmunka, a közös döntések és a közös szabályalkotás által valósul meg. A diákok megtanulhatják, hogyan kommunikáljanak egymással és a tanárral, annak érdekében, hogy fejlődni tudjanak a játék során és a tudásukban egyaránt. Előfordulhatnak olyan feladatok, amelyeket közösen kell megoldani. Így a versengés teret enged az együttmüködésnek, hiszen a közös jó érdekében kell cselekedni.

A tudásépítés is helyet kapott, hiszen a gamifikáció módszerének is első sorban az a célja, hogy a diák elsajátítsa a tananyagot. Ugyanakkor e mellett a tanuló saját maga építi ki a tudását, hiszen nincsen kézhez kapott információ. Prievara (2015) könyvében olyan példát hoz, mely során a tanulóknak egy bizonyos témakörben kell kutatómunkát végezniük, majd megosztaniuk a talált információkat társaikkal. Tehát a diákok lehetőséget kapnak arra, hogy maguk keressék meg egy feladat elvégzéséhez a szükséges anyagot.

A következő nagyon fontos képesség az információs és kommunikációs technológiai (IKT) eszközök használata. Amellett, hogy az IKT-használat szélesíti a tanár módszertani eszköztárát, a modern eszközök használata a tanítás során jobban leköti a tanulók figyelmét (Prievara, 2015). Ezen kívül hozzájárul a diákok technológiai tudásépítéséhez. A 21. századi gyerekek már a digitális eszközök világában nőnek fel, viszont ez nem jelenti azt, hogy helyesen tudják kezelni azokat. A tanóra keretein belül a tanár figyelemmel tudja kísérni a tanulókat, illetve megfelelő segítséget tud nyújtani.

A negyedik képesség a problémamegoldás. A „21. századi képességek rendszere azt mondja ki, hogy akkor működünk jól az oktatási rendszerben, ha az iskolán kívüli világban létező valós problémákra keressük a megoldásokat" (Prievara, 2015, p. 25). Tehát a tanórákra olyan feladatokat kell bevinni, melyek létező probléma köré összpontosulnak. Ez által a módszer lehetőséget ad arra, hogy a tanulók valós problémákra keressék a választ, ami hozzájárul ahhoz, hogy fejlödjön a kritikai gondolkodásuk is.

Az utolsó pont az önszabályozás, amit nem lehet elég korán elkezdeni tanulni. A tanulói autonómia hozzájárul ahhoz, hogy a tanulók megtanulják beosztani idejüket és a tervezés mellett megtanulják esetleg újratervezni azt. A diákoknak tekintettel kell lenniük társaikra is, hiszen nem lehet 45 percben mindenkinek minden feladatot teljesítenie. Így a tanulóknak egyeztetniük kell (a tanár vezetésével), hogy ki, mikor szeretne egy-egy feladatot teljesíteni (amennyiben azt a tanóra keretei között kell/lehet elvégezni) és az egyeztetés alapján kell beosztaniuk saját lehetőségeiket.

A 21. századi képességek fejlesztése mellett is számos pozitívumot lehet kiemelni. Ahogy azt már korábban említettük, minden tanuló nulláról indul. Ezáltal a tanulók elsődlegesen pozitív visszajelzést kapnak, nem a hibáikra esik a hangsúly, valamennyi más iskolai módszerrel ellentétben. Mivel a „számonkérés" folyamatos, a diákoknak nem kell azon izgulniuk, amennyiben rosszul sikerül valami, akkor esetleg nehezen tudják majd kijavítani. Így a vizsgadrukk nem veti vissza a tanulók teljesítményét. A folyamatos kommunikáció a tanulók között, illetve a tanár és a tanulók között pozitívan hat 
az osztályközösségre és a tanár diákokkal való kapcsolatára is. A korábban említett önszabályozás mellett a tanulókat nemcsak az önállóságra neveli, de megtanulják hogyan állítsanak fel rövid és hosszú távú célokat úgy, hogy azok teljesíthetőek legyenek (Gábris, 2019).

\section{Gamifikáció az oktatásban}

\section{Gamifikációs applikációk}

A gamifikáció módszerét már számos helyen alkalmazzák, külföldön az oktatásban is egyre gyakoribb. Magyarországon is egyre több tanár tud beszámolni tapasztalatiról a módszer kapcsán. Több internetes felületet is létrehoztak, melyek segíthetnek nyomon követni a tanulók fejlődését, a pontozást, illetve az értékelést is leegyszerűsíthetik.

Fromann Richárd és Damsa Andrei (2016) munkája alapján a következő virtuális felületeket állnak a gamifikációs módszer rendelkezésére:

1. ClassDojo (https://www.classdojo.com/)

A ClassDojo egy olyan online osztályterem, amely köteléket biztosít a tanárok, a szülők és a diákok között. A program célja nem az, hogy egy ideális osztálytermet hozzon létre, hanem hogy olyan felületet biztosítson, amely az aktuális közösség számára a legmegfelelőbb.

2. GoalBook (https://goalbookapp.com)

A GoalBook olyan internetes felület, mely lehetőséget kínál a tanulók differenciálására. A tanár úgy tud utasítást adni, hogy az minden diákhoz elér. A felület alkalmas különféle tanulási stratégiák alkalmazására, így a tanulók a saját igényük szerint használhatják.

3. CourseHero (https://www.coursehero.com)

A CourseHero készítői olyan világot képzeltek el, ahol minden diák sikeres, magabiztos és felkészült. Az online tudásmegosztó felület több mint 30 millió kurzusspecifikus forrást biztosít videókkal, jegyzetekkel, magyarázattal.

4. Classcraft (http://www.classcraft.com)

A Classcraft célja, hogy a tanulás élményekben gazdag, kreatív, játékszerü folyamat legyen. Olyan módszereket használ, amelyek a mai diákok számára relevánsak, mint például a technológiai eszközök használata, a játékok és a történetmesélés. A program segítségével fejleszthető az együttmüködés, az empátia, a kifejező készség, a vezetői készségek, illetve a kommunikáció.

5. MinecraftEdu (http://minecraftedu.com)

A MinecraftEdu egy olyan játék, amely hozzájárul a kreativitás, az együttmüködés és a problémamegoldó képesség fejlesztéséhez egy olyan környezetben, mely számára csak a képzelet szabhat határokat. Az online felületen a tanulók személyre szabhatják karaktereiket, beszélgethetnek az osztálytársaikkal, segítséget kérhetnek, ha elakadnak és feladatokat oldhatnak meg. 
6. Kidblog (http://kidblog.org/home/blog)

A Kidblog egy olyan online felület, ahol a tanulók biztonságos keretek között megoszthatják egymással munkáikat. A diákok blogbejegyzéseket tehetnek közzé a megadott témákban, melyeket a társaik, tanáraik és szüleik is megtekinthetnek.

7. Classtools (http://www.classtools.net)

A Classtools egy olyan online gyüjtőfelület, ahol az oktatásban is hasznos játékok találhatóak. Számos lehetőség közül választhatnak a felhasználók. Például, iskolai/osztálytermi naptárat lehet létrehozni, (ál)Facebook felületet lehet készíteni, illetve sok más játék elkészítését teszi egyszerübbé.

8. OkosDoboz (http://www.okosdoboz.hu)

Az OkosDoboz elnevezésű program egy olyan, elsősorban általános iskolás gyerekeknek szóló digitális taneszköz, amely fejleszti a diákok gondolkozási képességét, az ismeretek elsajátításához gyakorló feladatokkal és grafikus feladatsorokkal járul hozzá, valamint oktató videókat is tartalmaz.

9. Classbadges (www.classbadges.com)

A Classbadges egy olyan felület, mely az osztálytermi használatra fókuszál. A jutalmazáson alapul, így a tanulók jelvényeket, kaphatnak bizonyos feladatok teljesítése után. A tanulók teljesítménye grafikusan is megjelenik, a feladatok hozzájárulnak a belső motiváció kialakulásához.

A fent említett applikációkon kívül a módszerhez alkalmas lehet még a Google Classroom alkalmazás is. A tanári felületen létre lehet hozni kurzusokat, amelyekhez e-mail-cím segítségével lehet hozzáadni a tanulókat. A tanár létrehozhat különböző feladatokat, melyeket a tanulóknak ezen a felületen kell beadnia. Egyszerüen követhetők az eredmények és a személyes fejlődés egyaránt.

\section{Motiválás iskolai környezetben gamifikációval}

A pedagógusok egyik legnagyobb kihívása az, hogy hogyan motiválják a diákokat, hiszen a digitális világban, amikor szinte bármilyen információt meg lehet találni az interneten, a diákok nem elég motiváltak a tanuláshoz.

A motiváció létfontosságú a tanulási folyamat során, valamint befolyásolja a tanulás minőségét. Megkülönböztethetünk külső és belső motivációt. A belső motiváció egyfajta mozgatórugó, az egyén belső késztetést érez arra, hogy megtegyen valamit. A cselekvés bekövetkezte után elégedettség érzet, valamint pozitív érzések a jellemzők.

A külső motiváció egy kívülről érkező késztetés. A tanuló azért csinál valamit, hogy egy célt elérjen, például megdicsérjék, jó jegyet kapjon, ne bukjon meg. Tehát külső motiváció figyelhető meg akkor, ha egy pozitív dolgot szeretne elérni a diák, vagy ha egy negatívat szeretne elkerülni. A külső motiváció gyakran rövidtávú célt szolgál, a belső motiváció az, amelyet tartósan szükséges fenntartani (Polonyi \& Abari, 2017). 
A gamifikáció alkalmazása során szintén fontos szerepet tölthet be az elsajátítási motiváció. Józsa (2000) arról ír, hogy az elsajátítási motiváció jelenik meg azoknál, akik számítógépes játékokkal játszanak. A játék során a játékosok újabb és újabb kihívásokkal kell, hogy szembenézzenek, melyek folyamatosan nehezednek. A játékosok annak ellenére motiváltak a cél teljesítésében, hogy a siker garantált lenne, mégis egyre több pontot akarnak szerezni és a legmagasabb szintig eljutni. Ez a fajta motiváltság jelenhet meg a gamifikáció használata során is, mivel a módszer szerkezete az ilyesfajta játékok jutalmazási rendszerén alapul. A játékosok szerepét a tanulók töltik be, a tanórai feladatokat teljesítik, melyek a magasabb szinten nehezednek. A látszólagos cél, hogy a tanuló eljusson a legmagasabb szintre. Azonban ez által a tanuló motivált a tanulásra és a cél elérésével a tanulási célokat is eléri.

A motivációra különösen fontos szerep hárul az ének-zene oktatása során. Több hazai kutatás is arról számol be, hogy a tanulók nem elég motiváltak az énekórákon, közömbösek a tantárgy iránt, vagy nem szeretik azt (Janurik \& Józsa, 2018; Janurik et al., 2020, 2021). A tanulók motiválatlanságához hozzájárulhat a negatív zenei énképük. A tanulók sok esetben nem érzik magukat elég felkészültnek bizonyos zenei készségeket igénylő feladatok megoldásához, valamint az énekléshez sem (Janurik et al., 2020). Szintén hozzájárulhat a negatív képhez, hogy a tanulók nem érzik a fejlődést magukon, nincsen sikerélményük az órákon (Janurik \& Józsa, 2018). Az említett tanulmányok az ének-zene oktatás megreformálásának szükségességére világítanak rá. Olyan módszerek használatát javasolják, melyek segítségével a tanulók örömmel és aktívan vehetnek részt az énekórákon (Janurik \& Józsa, 2018; Janurik et al., 2020, 2021).

Jakobicz és munkatársai (2018) kutatást végeztek arról, hogy az ének-zene órák keretében kipróbált módszerek közül melyik típus mennyire motiválja a tanulókat. A legkedveltebb módszernek a drámapedagógiából vett „jelenetképek" bizonyult, hiszen ennél a módszernél a tanulók felállhattak, a megszokott egész napos ülésből kimozdulhattak.

A frontális munkával ellentétben kedvelt volt a kooperatív munkaforma, a tanulók örültek, hogy más órákhoz hasonlóan az ének-zene órán is csoportosan dolgozhattak. A projektmódszer alkalmazásánál a tanulók olyan témát választhattak, amit ők szerettek volna kidolgozni, majd PPT-vel mutatták be az előadásaikat. A problémaalapú oktatás is motiválóan hatott a diákokra, a módszer teljesen újszerü volt a kutatásba bevont tanulók körében. A kutatás eredménye alapján a tanulókra motiválóan hatottak a felsorolt, általuk kipróbált módszerek. Örültek, hogy a tanár kíváncsi volt a véleményükre. Megfogalmazták, fontos számukra a változatosság, ahhoz, hogy tartósan tudják koncentrálni a figyelmüket a tanulásra. Tehát a különböző módszerek alkalmazása, illetve az órák változatossága nagyban hozzájárul a diákok motivációjához.

A gamifikáció számos pozitív hatása közül talán legfontosabbnak az mondható, hogy a tanulók motiváltabbak lesznek a módszer alkalmazása- 
kor, így fokozódik a teljesítményük. Ha minden tevékenységnél nem is alkalmazható a módszer, motiváló hatással bír a tanulókra az, hogy saját maguk választhatják ki a feladatokat, amiket elvégeznek, emellett különböző tevékenységekben vehetnek részt (Polonyi \& Abari, 2017). Dolgozhatnak csoportokban, választhatnak olyan általuk kedvelt témát, amit önállóan dolgoznak ki, kérhetnek segítséget a tanártól, kereshetnek információt az interneten, összedolgozhatnak a társaikkal. A fö feladattípusokon belül számtalan lehetőség van arra, hogy mindenki megtalálja azt, amiben a legjobb, illetve kipróbáljon új dolgokat és fejlődjön olyan területen, ami nem az erössége. A fent leírt kutatás alapján a gamifikáció módszere hozzájárul a diákok motiváltságához, hiszen a segítségével változatosak a tanórák, ez által jobban lekötik a tanulók figyelmét.

\section{A gamifikáció megjelenése a zene oktatásában}

A gamifikációt egyre gyakrabban használják az oktatásban, viszont a zeneoktatásban még kevés példa található rá és még kevesebb magyar példa. Az alábbiakban három idegen nyelvü és egy magyar nyelvü tanulmányt mutatok be, ahol azt vizsgálták milyen hatással lehetnek a gamifikáció bizonyos formái az ének-zene, illetve az zeneoktatásban. A módszerek különbözősége rávilágít arra, hogy a gamifikációt sokféleképpen lehet alkalmazni és igény szerint formálni.

\section{Gamifikáció a zene oktatásában - A Technique Tower módszer}

Birch és Woodruff (2017) kutatása egyéni zongoraórákra járó diákok körében zajlott. Arra a kérdésre keresték a választ, hogy az otthoni gyakorlást hogyan lehetne befolyásolni, illetve hogyan lehetne a diákokat motiválni arra, hogy a különféle technikai gyakorlatokat (például skálázás), amiket a legtöbb tanuló nem kedvel, eredményesen gyakorolják. A motiváció érdekében a gamifikáció játékos elemeit alkalmazták. Arra az eredményre számítottak, hogy ezzel motiváltabbak lesznek a diákok, több időt fognak szánni otthon a gyakorlásra és így gyorsabban fognak fejlődni (Birch \& Woodruff, 2017).

A kutatásban résztvevő tanulóknak a technikai gyakorlatok játszásával pontokat kellett szerezni, illetve szinteket lépni. Számukra a cél az volt, hogy minél magasabbra jussanak a Technikák Tornyán (Technique Tower). A pontjaikat és az elért szintjeiket egy online felületen láthatták, ahol virtuális trófeákat és bónuszokat is kaphattak, valamint saját avatárokat, karaktereket hozhattak létre (Birch \& Woodruff, 2017).

A kilenc hétig tartó kutatást egy kísérleti csoport és egy kontrollcsoport segítségével végezték, valamint a kutatás végén kérdőíveket kellett a diákoknak kitölteniük. A kísérleti csoportban részt vevő tanulók egy útmutatót kaptak a technikai gyakorlatokról, melyek közül szabadon választhattak, hogy mikor melyiket gyakorolják. Ha egy adott gyakorlatot a tanárnak eredményesen 
bemutattak, arról hangfelvétel készült és felkerült az online felületre, ahol a szülők, a tanárok, illetve a tanulótársak számára is elérhetővé vált. A kísérleti csoporttal ellentétben a kontrollcsoport nem részesült a játékos elemekben. Az ö feladatuk az volt, hogy egy adott hangnemben egy hétig gyakorolják az oda kapcsolódó technikai gyakorlatokat, majd mutassák be a tanáruknak. Ha a következő óra alkalmával a tanár úgy ítélte meg, hogy elfogadhatóak a gyakorlatok, akkor szóbeli dicséretet kapott a tanuló és tovább mehetett egy másik hangnemre. Viszont, ha a gyakorlatok nem voltak elfogadhatóak, akkor újabb egy hétig kellett azokat gyakorolni (Birch \& Woodruff, 2017).

A kutatás eredménye szerint azok a tanulók, akik a gamifikációs módszerrel gyakorolhattak, sikeresebbnek bizonyultak a zongorai technikák elsajátításában, mint a kontrollcsoport tanulói. Viszont a diákok hozzáállása ezeknek a gyakorlatoknak az otthoni gyakorlásához csak szerény mértékben változott. Összességében a tanulók élvezték az új módszert és a gamifikációs módszer pozitív hatással volt a teljesítményükre (Birch \& Woodruff, 2017).

\section{Gamifikáció az ének-zene tanitásban - A Musical Journey módszer}

Gomes és munkatársai (2014) által végzett kutatás 9 és 11 éves kor közötti tanulók körében zajlott Portugáliában, állami iskolák ének-zene óráján. A zenetörténet tanulása során a tanulók hallanak a zenetörténeti korszakokról, a zeneszerzőkről a hangszerekről és a kortárs művészetről, viszont ezek gyakran szárazan, előadásszerüen hangzanak el az órákon. A kutatás azt vizsgálta, hogy a zenetörténet oktatását hogyan lehetne izgalmasabbá, illetve motiválóbbá tenni. Arra az eredményre számítottak, hogy amennyiben a zenetörténetet virtuális valóságon keresztül, gamifikációs elemekkel tanulhatják a diákok, akkor motiváltabbak lesznek. Azokra a kérdésekre keresték a választ, hogy a tanulóknak mi a véleményük a programról, mennyire tartják használhatónak, mennyire fontosak számukra a játékos elemek és mik azok a tényezők, amik valóban hozzájárulnak a tanulásukhoz (Gomes et al., 2014).

A kutatásban részt vevő tanulók egy 3D-s virtuális valóság programban, az úgynevezett Musical Journey-ben (zenei utazás) vehettek részt. A program múzeumhoz, galériához hasonló szobákban zajlott, ahol a zenetörténet különböző részei voltak kiállítva. Minden szoba fö kiállítása az adott zenetörténeti korszak leghíresebb zeneszerzőiről, életükről és munkásságukról szólt.

Emellett megtekinthető volt egy idővonal a zeneszerzőkről, képek a kor hangszereiről és négy festmény az adott korból. A programban a tanulók szerezhettek pontokat, léphettek szinteket, mindezt egy ranglétrán láthatták, valamint segítséget nyújthattak egymásnak, ha elakadtak. A cél az volt, hogy megtanulják a zenetörténeti korszakok legfontosabb alakjait, kultúráját, illetve a zenetörténetről, mint egészről alkossanak képet. Egy periódusban két zenetörténeti korszakot fedezhettek fel a diákok. Ez után tesztet töltöttek ki, ami, ha elérte az 50\%-ot, akkor továbbhaladhattak, ha nem érte el, akkor 
meg kellett ismételniük a korszakokat, így a tanulók folyamatos visszacsatolásban részesültek (Gomes et al., 2014).

A program tesztelése után a tanulók kérdőívet töltöttek ki. A kérdőív alapján a diákok elégedettek voltak a programmal, a használatát egyszerünek tartották. Úgy gondolták, könnyủ volt számukra a tanulás, a program megfelelően működött, következetes volt és magabiztosan tudták használni. A kutatás szerint a gamifikáció (és a virtuális valóság) pozitív hatással volt a tanulók zenetörténet tanulására (Gomes et al., 2014).

\section{Gamifikáció a zenetanulásban - IKT bevonásával}

A tanulás során meghatározó szerepe van a motivációnak, a zenetanulás során még inkább. A gamifikáció a zenetanulásban IKT-eszközök bevonásával kutatás fő kérdése az volt, hogy a multimédiás eszközök használata hozzájárul-e a metakogníció elősegítéséhez. A kutatás oktatás-fejlesztési célja, hogy egy applikáció használatával minőségi tanulási lehetőséget nyújtsanak a tanulók számára az zeneoktatában. A kutatás során a tanulók olyan alkalmazást használtak 8 héten keresztül, amely alapvetően a gitár gyakorláshoz és háttérvokál énekléshez nyújt segítséget (Gomes et al., 2014).

A kutatás 10 és 13 éves tanulók körében zajlott, portugál általános és középiskolákban. A résztvevő tanulók városi környezetben nevelkedtek, a szülők többsége általános iskolai végzettséggel rendelkezett, illetve a diákok többségénél nem volt kilátásban az egyetemi továbbtanulás. Minden tanuló rendelkezett internet-hozzáféréssel, illetve mindenki részesült iskolai zeneoktatásban. Három különböző csoport vett részt a vizsgálatban: egy csoport, akik a tanóra keretein belül használták az applikációt, egy másik csoport, akik a Moodle felület segítségével gamifikációs formában használták az applikációt és egy kontrollcsoport.

A kutatás során azt vizsgálták, az IKT-eszközök használata mennyire befolyásolja a tanulók elköteleződését, milyen típusú motiváció jelenik meg a tanulóknál (külső vagy belső), megosztják-e a diákok az elsajátított tudásukat, illetve ezek az adatok mennyiben térnek el a kontrollcsoport adataitól (Gomes et al., 2014).

A kísérleti csoportok közül a gamifikációs módszerrel tanuló diákok eredményei lettek a legpozitívabbak. Ennek a csoportnak a tanulói készültek a legtöbbet az órára, ők voltak a legmotiváltabbak, közülük osztották meg a legtöbben az elsajátított tudást a családjukkal, barátaikkal és a végső teszten minden diák 50\%-os eredmény fölött teljesített. A kutatás eredménye azt mutatja, azoknál a tanulóknál, akik az alkalmazást a gamifikáció módszerével egybekötve használták, nagyobb volt a belső motiváció, illetve a vizsgált területeken kimagasló eredményt nyújtottak (Gomes et al., 2014). 


\section{Gamifikáció az ének-zene oktatásában - A Zenesziget program}

Magyarországon a gamifikáció módszerével még kevés helyen lehet találkozni az ének-zene oktatásban. A Szabó Norbert által fejlesztett, Zenesziget elnevezésű program egy Androidra és Windows-ra kifejlesztett alsótagozatsoknak szóló applikáció. Az oktatóprogram célja, hogy az IKT-eszközök alkalmazásával motiválja a tanulókat, illetve játékos módon fejlessze a zenei képességeket, - mint például a kottaolvasást, a ritmusérzéket és a befogadó készséget -, a tanterv által elöírt követelményekre támaszkodva (Szabó, 2018).

A felületen több platform közül választhatnak a felhasználók. A Hangerdóben a diákok megismerkedhetnek különböző effektekkel, a hangszercsoportok tagjaival és azok hangjával, állathangokkal, a természet hangjaival és jármüvek hangjaival. A Zenetárban digitális kottákat találhatnak, zenét hallgathatnak, karaokevideó segítségével énekelhetnek. A Játékkuckóban 12 játék közül választhatnak, például zenevonat, dominó, memória. Ezenkívül a tanulók ellátogathatnak a Ritmussíkságra vagy Hangköztársaságba is (Szabó, 2018).

A kutatást Szegeden végezték, öt első osztály 142 tanulója vett részt benne. Az ének-zene órákon 10-15 percet foglalkozhattak a gyerekek táblagépes munkával, amit az eszközök megóvása érdekében tanári asszisztálás kísért. A tanulók dolgoztak önállóan és közösen, hallgattak zenét, hangszerfelismerő feladatokat végeztek és énekeltek (Szabó, 2018).

A program felhasználói felülete, zenei anyagai pozitív visszajelzésnek örvendenek. A kutatásban részt vevő diákok kedvenc funkciója a karaokevideó volt. Az eredmények alapján a tanulókat motiválta, hogy zenei kísérettel együtt énekelhettek. A gyerekek nagyon élvezték a táblagépes foglalkozásokat (Szabó, 2018).

A programmal kapcsolatos későbbi kutatás már azt mutatja, hogy a Zenesziget applikáció használata pozitívan hat a tanulók zenei képességeire. A kutatásban 135 tanuló vett részt a kísérleti csoportban és 111 tanuló a kontrollcsoportban. Az alkalmazásnak köszönhetően a kísérleti csoport tanulóinak ének-zene órával kapcsolatos attitüdje pozitívabb volt a kontrollcsoport tanulóihoz képest. Emellett a program segítette a zenei írás és olvasás fejlődését, a tanulók jobban megismertek bizonyos hangszereket, valamint az éneklési képességeik egyaránt pozitívan változtak. A program sikeressége azt mutatja, hogy a Zenesziget applikáció használata hatékony lehet az énekzene oktatás során a tanulók motivációjának növelésére, az ének-zene tantárgyhoz való hozzáállás pozitív változtatására (Szabó et al., 2019).

\section{Összegzés}

A tanulmány definiálta a gamifikáció fogalmát. A gamifikáció játékos elemek használata nem játékos környezetben. Röviden ismertette a gamifikáció kialakulásának történetét, illetve müködési elvét, egyben rávilágított arra, 
hogy milyen nagyban hozzájárulhat a módszer a diákok motiválásához. Példákat mutattunk arra, hogy milyen applikációk segítségével lehet alkalmazni a módszert tantermi környezetben, illetve hogyan alkalmazták már a módszert a zeneoktatás különböző területein.

A módszer lehetőséget nyújt arra, hogy a tanítás és tanulás folyamatát a tanulók szórakozásként éljék meg, ezáltal a tanórán jó hangulat alakulhat ki. A módszer alkalmazása során a tanulók megtanulhatnak csoportban dolgozni, saját maguknak kell beosztaniuk az idejüket, több típusú feladat közül választhatják ki a számukra szimpatikusakat, valamint különböző információkat kell összegyüjteniük a tananyag kapcsán, így fejlődhet kritikai gondolkodásuk is.

A tanulmányban bemutatott kutatások alapján a zeneoktatásban, illetve az ének-zene órákon is pozitív hatás érhető el hasonló módszerek alkalmazásával. Hiszen azon kívül, hogy egy jó hangulatú énekóra segíthet a diákoknak kikapcsolódni, a közös éneklés és zenélés jó hatással lehet az osztályközösségre, a tanulók közötti kommunikációra, illetve számos készség és képesség fejlesztésére alkalmas.

\section{Köszönetnyilvánítás}

A tanulmány az Innovációs és Technológiai Minisztérium ÚNKP-21-2SZTE-294 Kódszámú Új Nemzeti Kiválóság Programjának a Nemzeti Kutatási, Fejlesztési és Innovációs Alapból finanszírozott szakmai támogatásával készült.

\section{Irodalom}

Bartle, R. (2004). Designing virtual worlds. New Riders.

Birch, H. JS \& Woodruff, E. (2017). Technical exercise practice: Can piano students be motivated through gamification? Journal of Music, Technology \& Education, 10(1), 31-50. https://doi.org/10.1386/jmte.10.1.31_1

Cambridge Dictionary.https://dictionary.cambridge.org/dictionary/english/gamification Chrappán, M. (2017). A természettudományi tárgyak helyzete és elfogadottsága a közoktatásban. Magyar Tudomány, 178(11), 1352-1368. https://doi. org/10.1556/2065.178.2017.11.3

Christians, G. (2018). The Origins and Future of Gamification. University of South Carolina. https://scholarcommons.sc.edu/senior_theses/254/

Csíkos, Cs. (2012). Melyik a kedvenc tantárgyad? Tantárgyi attitüdök vizsgálata a nyíltvégủ írásbeli kikérdezés módszerével. Iskolakultúra, 12(1), 3-13.

Fromann, R. \& Damsa, A. (2016). A gamifikáció (játékosítás) motivációs eszköztára az oktatásban. Új Pedagógiai Szemle, 66(3-4), 76-81.

Fromann, R. (2017). Játékoslét. A gamifikáció világa. Typotex. 
Gábris, Z. (2019). Gamifikáció az oktatásban - avagy hogyan motiváljuk tanulásra az Alfa és $Z$ generációt? https://mindsetpszichologia.hu/gamifikacio-azoktatasban-avagy-hogyan-motivaljuk-tanulasra-az-alfa-es-a-z-generaciot

Gomes, C., Figueiredo, M. \& Bidarra, J. (2014). Gamification in teaching music: Case study. In EduRe 14 proceedings. International Virtual Conference on Education, Social and Technological Sciences (pp. 1-19). Valência: Universidade Politécnica de Valência http://hdl.handle.net/10400.2/3478

Gomes, J., Figueiredo, M. \& Amante, L. (2014). Musical Journey: A virtual world gamification experience for music learning. International Journal on Advances in Education Research, 1(1), 1-21.

Jakobicz, D., Wamzer, G. \& Józsa, K. (2018). Motiválás az ének-zene órákon. Gyermeknevelés Tudományos Folyóirat, 6(2), 18-31. https://doi.org/10.31074/ gyn 201821831

Janurik, M. \& Józsa, K. (2018): Az iskolai zenetanulás iránti motivációt alakító néhány tényező. Gyermeknevelés Tudományos Folyóirat, 6(2), 5-17. https://doi. org/10.31074/gyn20182517

Janurik, M., Kis N., Szabó N. \& Józsa K. (2021). Az ének-zene tantárgy iránti attitűd összefüggése az iskolai zenetanulás iránti motivációval hetedik osztályos tanulók körében. Neveléstudomány: Oktatás-Kutatás-Innováció, 3(2), 17-42. https:// doi.org/10.21549/NTNY.33.2021.2.2

Janurik, M., Szabó, N. \& Józsa, K. (2020). A zenei énkép jellemzői és összefüggése a zenei képességekkel hetedik osztályosok körében. Magyar Pedagógia, 120(2), 171-200. https://doi.org/10.17670/MPed.2020.2.171

Józsa, K. (2000). Az elsajátítási motiváció szerepe a kritériumorientált pedagógiában. Új Pedagógiai Szemle, 50(10), 78-82.

Koivisto, J. \& Hamari, J. (2019). The rise of motivational information systems: A review of gamification research. International Journal of Information Management, 45, 191-210. https://doi.org/10.1016/j.ijinfomgt.2018.10.013

Kusuma, G. P., Wigati, E. K., Utomo, Y. \& Suryapranata, L. K. P. (2018). Analysis of Gamification Models in Education Using MDA Framework. Procedia Computer Science, 135, 385-392. https://dx.doi.org/10.1016/j.procs.2018.08.187

Malone, T. W. (1981). Toward a theory of intrinsically motivating instruction. Cognitive Science, 5(4), 333-369. https://doi.org/10.1207/s15516709cog0504_2

Marczewski, A. (2014). Defining gamification - what do people really think? https:// www.gamified.uk/2014/04/16/defining-gamification-people-really-think

Pelling, N. (2011). The (short) prehistory of "gamification”... https://nanodome. wordpress.com/2011/08/09/the-short-prehistory-of-gamification/

Pintér, T. K. (2018). A zenei nevelés megítélése általános iskolás tanulók körében. In Váradi, J. \& Szűcs, T. (Eds.), A zenepedagógia múltja, jelene és jövője (pp. 205219). Debreceni Egyetemi Kiadó. https://doi.org/10.31074/gyntf.2020.2.74.109 
Pintér, T. K. (2020). A zeneoktatásunk kihívásai és nehézségei általános iskolai és gimnáziumi énektanárok nézetei alapján. Gyermeknevelés Tudományos Folyóirat, 8(2), 74-109. https://doi.org/10.14232/ISKKULT.2020.7.3

Pintér, T. K. \& Csíkos, Cs. (2020). Tanulók, szülők és tanárok perspektívái az iskolai zenei nevelés céljáról és feladatáról. Iskolakultúra, 30(7), 3-25.

Polonyi T., \& Abari K. (2017). A gamifikáció motivációs eszközei a nyelvoktatásban. http://inyelv.unideb.hu/files/btan/a_gamifikacio.pdf

Prievara, T. (2015). A 21. századi tanár. Neteducatio Kft.

Szabó, N. (2018). Zenesziget. Játékosítás (gamifikáció) digitális eszközökkel az énekzene oktatásban. Gyermeknevelés Tudományos Folyóirat, 6(2), 97-107. https:// doi.org/10.31074/gyn2018297107

Szabó, N., Janurik, M. \& Józsa, K. (2019). The effect of Music Island (computer program) on the development of musical abilities in school Music lessons. In L. Gómez Chova, A. López Martínez, \& I. Candel Torres (Eds.), EDULEARN19 Proceedings: 11th International Conference on Education and New Learning Technologies(pp.589-599).IATED.https://doi.org/10.21125/edulearn.2019.0212 


\section{Kiss, B. \& Asztalos, A.}

\section{Role of gamification in music education}

In this study we examined the extracurricular art activities of fourth grade primary school students and their opportunity to participate in cultural and artistic events. We explored whether artistic activity has an effect on attitudes toward events. In addition, we sought differences in the family backgrounds of those who attend and do not attend extracurricular art events. The results, in addition to highlighting the role of the school in balancing out cultural capital, confirm the strength of the impact of intergenerational transfer. If the parents were previously been involved in artistic activities, they will also be more supportive of their child in the field of arts. Students who engaged in some form of extracurricular artistic activity in their childhood are more likely to become cultural consumers in adulthood.

Keywords: art activity, attending an art event, art experience, cultural transfer

Kiss Bernadett: https://orcid.org/0000-0002-9060-8719

Asztalos Andrea: https://orcid.org/0000-0002-7584-3294 